\title{
Screening for bacterial DNA in the hard tick Hyalomma marginatum (Ixodidae) from Socotra Island (Yemen): detection of Francisella-like endosymbiont
}

\author{
M. Montagna, ${ }^{1}$ B. Chouaia, ${ }^{2}$ F. Pella, ${ }^{3}$ M. Mariconti, ${ }^{1}$ D. Pistone, ${ }^{1}$ M. Fasola, ${ }^{3}$ S. Epis ${ }^{1,4}$ \\ ${ }^{1}$ DIVET, Sezione di Patologia Generale e Parassitologia, Università degli Studi di Milano; \\ ${ }^{2}$ DEFENS, Università degli Studi di Milano; ${ }^{3}$ Dipartimento Scienze della Terra e dell'Ambiente, \\ Università di Pavia; ${ }^{4}$ Scuola di Bioscienze e Biotecnologie, Università degli Studi di Camerino, Italy
}

\begin{abstract}
Thirty-four adult ticks collected from livestock on Socotra Island (Yemen) were identified as Hyalomma marginatum using traditional morphological characteristics. Morphological identification was confirmed for all the collected specimens using a molecular approach targeting a fragment of the mitochondrial gene 12S rRNA. All the specimens were examined for the presence of tick-borne pathogens and the tick endosymbiont Candidatus Midichloria mitochondrii using polymerase chain reaction. Three specimens out of the 34 analyzed tested positive to the presence of Francisella spp. leading to the first detection of these bacteria in H. marginatum on Socotra Island. The phylogenetic analyses conducted on a 660 bp fragment of the ribosomal gene 16S rRNA of Francisella spp. (including F. philomiragia as outgroup, the four subspecies of $F$. tularensis and the Francisella-like endosymbiont of ticks) confirm that the newly detected Francisella
\end{abstract}

Correspondence: Sara Epis, DIVET, Sezione di Patologia Generale e Parassitologia, Università degli Studi di Milano, via Celoria 10, 20133 Milano, Italy. Tel. +39.02 .5031 .8094 - Fax: +39.02 .5031 .8095 .

E-mail: sara.epis@guest.unimi.it

Key words: ticks, tick-borne pathogens, Francisella-like tick endosymbionts, Socotra Island.

Acknowledgments: the research was conducted under the United Nations Program, UNDP and under the Socotra Archipelago Conservation. The Authors would like to thank Dr. Lorenza Beati and Dr. Agustin Estrada-Peña for their valuable suggestions, and Dr. Massimo Pajoro for methodological support.

Received for publication: 31 May 2012.

Revision received: 4 October 2012.

Accepted for publication: 14 November 2012.

(C) Copyright M. Montagna et al., 2012

Licensee PAGEPress, Italy

Journal of Entomological and Acarological Research 2012; 44:e13

doi:10.4081/jear.2012.e13

This article is distributed under the terms of the Creative Commons Attribution Noncommercial License (by-nc 3.0) which permits any noncommercial use, distribution, and reproduction in any medium, provided the original author(s) and source are credited. strains cluster into the Francisella-like endosymbionts of ticks. Interestingly, the detected Francisella-like endosymbiont, shows a different genotype to that previously isolated from $H$. marginatum collected in Bulgaria. No specimen was positive for the presence of Rickettsia spp., Coxiella burnetii, Borrelia burgdorferi or M. mitochondrii.

\section{Introduction}

Ticks are blood-sucking ectoparasites able to parasite a multitude of terrestrial vertebrates such as mammals, birds, reptiles and amphibians (Sonenshine, 1991, 1993). Nowadays, ticks are considered to be the group of arthropods that can transmit the widest variety of pathogenic agents to humans and animals (Jongejan \& Uilenberg, 2004). Microorganisms such as bacteria (e.g., Rickettsia spp., Borrelia burgdorferi, Erlichia spp. and Francisella spp.), protozoa and viruses (like Crimean-Congo hemorragic fever, Tick Borne Encephalitis) can be transmitted to the host as a result of a tick bite (Sonenshine, 1991; Jongejan \& Uilenberg, 2004). Ticks also play an important role as reservoirs for populations of these bacteria in nature (Parola \& Raoult, 2001). Recently, the intra mitochondrial bacterium Candidatus Midichloria mitochondrii (hereafter M. mitochondrii; Sassera et al., 2011), originally discovered in the tick Ixodes ricinus, was found to be widespread in many tick genera (Lo et al., 2006; Epis et al., 2008).

Approximately 870 species of ticks are described (Nava et al., 2009), subdivided into three families: Argasidae, Ixodidae and Nuttalliellidae (Horak et al., 2003; Nava et al., 2009). The 26 species belonging to the genus Hyalomma Koch, 1844 are widespread in Palearctic and Afrotropical biogeographic regions (Horak et al., 2003; Apanaskevich \& Horak, 2008; Estrada-Peña et al., 2012). Hyalomma marginatum Koch, 1844 is widespread in Central and Southern Europe, North Africa and in Asia, eastwards to Iran (Manilla, 1998; Apanaskevich \& Horak, 2008). H. marginatum is a 2-host species showing a low host specificity. In fact, the adults feed on different species of large mammals (ungulates and livestock) while the immature individuals feed on birds or small mammals (Manilla, 1998) increasing their ability to spread. This species can transmit a variety of pathogens to humans and animals (Hoogstraal, 1956) and is considered one of the most important tick species involved in the transmission of the virus of the Crimean-Congo hemorrhagic fever (Hoogstraal, 1979; Estrada-Peña et al., 2012). Furthermore, it is known to transmit bacteria of the genus Rickettsia (e.g., $R$. conori the causative agent of the Mediterranean spotted fever) and Coxiella burnetii, the causative agent of Q-fever (Hoogstraal, 1956). Recently, Ivanov and colleagues (2011) isolated Francisella-like endosymbionts (FLEs) in H. marginatum collected from Bulgaria. 
This paper is a first study on ticks (Acarina, Ixodida) collected from Socotra Islan, an archipelago in the Indian Ocean, that has a particular fauna as it was isolated 35-41 million years ago (Girdler \& Styles, 1974). The paper also reports the bacterial community associated with these ticks in this area.

\section{Materials and methods}

\section{Sample collection, morphological identification and image acquisition}

A total of 34 adult tick specimens were collected on Socotra Island, Yemen, directly from livestock (10 specimens from 3 sheep and 24 from 5 goats, respectively) during field research in December 2010. All the collected specimens were immediately stored in absolute ethanol for further DNA extraction. Genomic DNA was extracted from all specimens individually following a procedure that allows the morphology to be preserved for further analyses. Specimen manipulation was completed using the Leica MS5 stereomicroscope (Leica Microsystems $\mathrm{GmbH}$, Wetzlar, Germany). All ticks were identified using standard taxonomic keys (Starkoff, 1958; Manilla, 1998; Apanaskevich \& Horak, 2008). Male and female images were acquired by a machinery made and C-optimized in order to scan the sample at different focus layers that were mounted with a 1.064 bit Zerene Stacker (Student Edition; Zerene Systems LLC, Richland, WA, USA).

\section{DNA extraction and polymerase chain reaction}

Total genomic DNA was extracted and purified individually using Qiagen DNeasy Blood and Tissue Kit (Qiagen, Hilden, Germany). All the ticks preserved in ethanol were washed with distilled water and dried before DNA extraction. Ticks were then cut with a scalpel along the idiosome and left for $12 \mathrm{~h}$ at $56^{\circ} \mathrm{C}$ in $180 \mu \mathrm{L}$ of ATL lysis buffer (Qiagen) with $200 \mathrm{ng} / \mathrm{mL}$ proteinase K (Sigma Aldrich, St. Louis, MO, USA). Extraction was performed according to the manufacturer's instructions. In detail, extracted DNAs were quantified with Nanodrop 1000 (Thermo Scientific, Wilmington, DE, USA). In order to confirm the morphological identification of the ticks, a fragment of the mitochondrial ribosomal small subunit 12S rRNA gene was amplified (Beati \& Keirans, 2001) and sequenced for all the samples. The extracted DNAs were examined, for the presence of Francisella spp., Rickettsia spp., C. burnetii, B. burgdorferi and $M$. mitochondrii, using specific polymerase chain reaction (PCR) protocols. The primers used for the screening of bacterial species are reported in Table 1. PCR amplification was performed in $25 \mu \mathrm{L}$ reaction mix containing: $1 \mathrm{X}$ GoTaq reaction Buffer (10 mM Tris- $\mathrm{HC}$ at pH 8.3, $50 \mathrm{mM} \mathrm{KCl}$ and $1.5 \mathrm{mM} \mathrm{MgCl} 2)$,
$0.2 \mathrm{mM}$ of each deoxynucleoside triphosphate, $0.5 \mathrm{pmol}$ of each primer, $0.625 \mathrm{U}$ of GoTaq DNA Polymerase and $50 \mathrm{ng}$ of template DNA. Successful amplification was determined by gel electrophoresis. Positive and unambiguous PCR products were directly sequenced in both strands by ABI technology (Applied Biosystems, Foster City, CA, USA). The obtained sequences were manually corrected using Geneious Pro 5.3 (Biomatters Ltd., Auckland, New Zealand) and deposited in the European Molecular Biology Laboratory data library (Accession numbers: H. marginatum partial 12S rRNA gene, HE819515; Francisella-like endosymbiont partial 16S rRNA gene, HE819516).

\section{Bioinformatic and phylogenetic analyses}

The tick mitochondrial $12 \mathrm{~S}$ rRNA and the bacterial $16 \mathrm{~S}$ rRNA consensus sequences obtained were subjected to BLAST analysis (http:/www. ncbi.nlm.nih.gov/blast) and compared to the sequences available in GeneBank (http:/www.ncbi.nlm.nih.gov/genbank/). A 16S rRNA sequence of Francisella spp. was retrieved from GeneBank in order to perform phylogenetic analyses. Sequences belonging to the four subspecies of Francisella tularensis, FLEs of tick and other Francisella spp. were included in the dataset (Accession numbers are reported in Figure 1). The 18 sequences obtained were aligned using MUSCLE (Edgar, 2004) then trimmed with Gblocks (Castresana, 2000) and analyzed with jModelTest 0.1.1 (Posada, 2008) to choose the most suitable model of nucleotide evolution. Phylogenetic reconstructions were performed with Bayesian inferences using MrBayes 3.1.2 (Huelsenbeck \& Ronquist, 2001). Bayesian analyses were performed using general time reversible (Lanave et al., 1984) as model of evolution $+\mathrm{I}+\mathrm{G}$; two parallel analyses, each composed of one cold and three incrementally heated chains were run for 2.5 million generations. Trees were sampled every 100 generations and burn-in fraction was calculated as $25 \%$ of total sampled trees, according to the likelihood scores (LnL) stationary analyses. The majority rule consensus tree was rooted with the branch leading to $F$. philomiragia and $F$. noatunensis, node with values of Bayesian posterior probability (BPP) less than 0.5 were collapsed (Figure 1). Pairwise p-distance between the FLEs sequence obtained in this study and the two closely related FLEs of Rhipicephalus sanguineus (HQ705171) and of H. m. marginatum (HQ705170) was calculated using MEGA 5 (Tamura et al., 2011).

\section{Results}

All the collected ticks, 11 males and 23 semi-engorged females, were morphologically identified as Hyalomma marginatum. Male and female images in dorsal view are reported in Figure 2. The DNA extracted from the 34 specimens, quantified by Nanodrop 1000, result in concentrations ranging from 40 to $110 \mathrm{ng} / \mu \mathrm{L}$. All tick samples were positive for

Table 1. Primers used for bacterial screening in the present study.

\begin{tabular}{|c|c|c|c|}
\hline Organism & Target gene & Primer sets & References \\
\hline Borrelia burgdorferi & 16S rRNA & $\begin{array}{l}\text { 5'-ATGCACACTTGGTGTTAACTA-3' } \\
\text { 5'-GACTTATCACCGGCAGTCTTA-3' }\end{array}$ & Marconi \& Garon, 1992 \\
\hline Coxiella burnetii & Transposon-like repetitive region & $\begin{array}{l}\text { 5'-TATTGTATCCACCGTAGCCAGTC-3' } \\
\text { 5'-CCCAACAACACCTCCTTATTC-3' }\end{array}$ & $\begin{array}{l}\text { Willems et al., 1994; } \\
\text { Berri et al., } 2000\end{array}$ \\
\hline Francisella spp. & 16S rRNA & $\begin{array}{l}\text { 5'-CAAGGTTAATAGCCTTGGGGGA-3' } \\
\text { 5'-GCCTTGTCAGCGGCAGTCTTA-3' }\end{array}$ & Forsman et al., 1994 \\
\hline Midichlori mitochondrii & 16S rRNA & $\begin{array}{l}\text { 5'-GTACATGGGAATCTACCTTGC-3' } \\
\text { 5'-CAGGTCGCCCTATTGCTTCTTT-3' }\end{array}$ & Epis et al., 2008 \\
\hline Rickettsia spp. & Citrate synthase gltA & $\begin{array}{c}\text { 5'-GCAAGTATCGGTGAGGATGTAAT-3' } \\
\text { 5'-GCTTCCTTAAAATTCAATAAATCAGGAT-3' }\end{array}$ & Labruna et al., 2004 \\
\hline
\end{tabular}




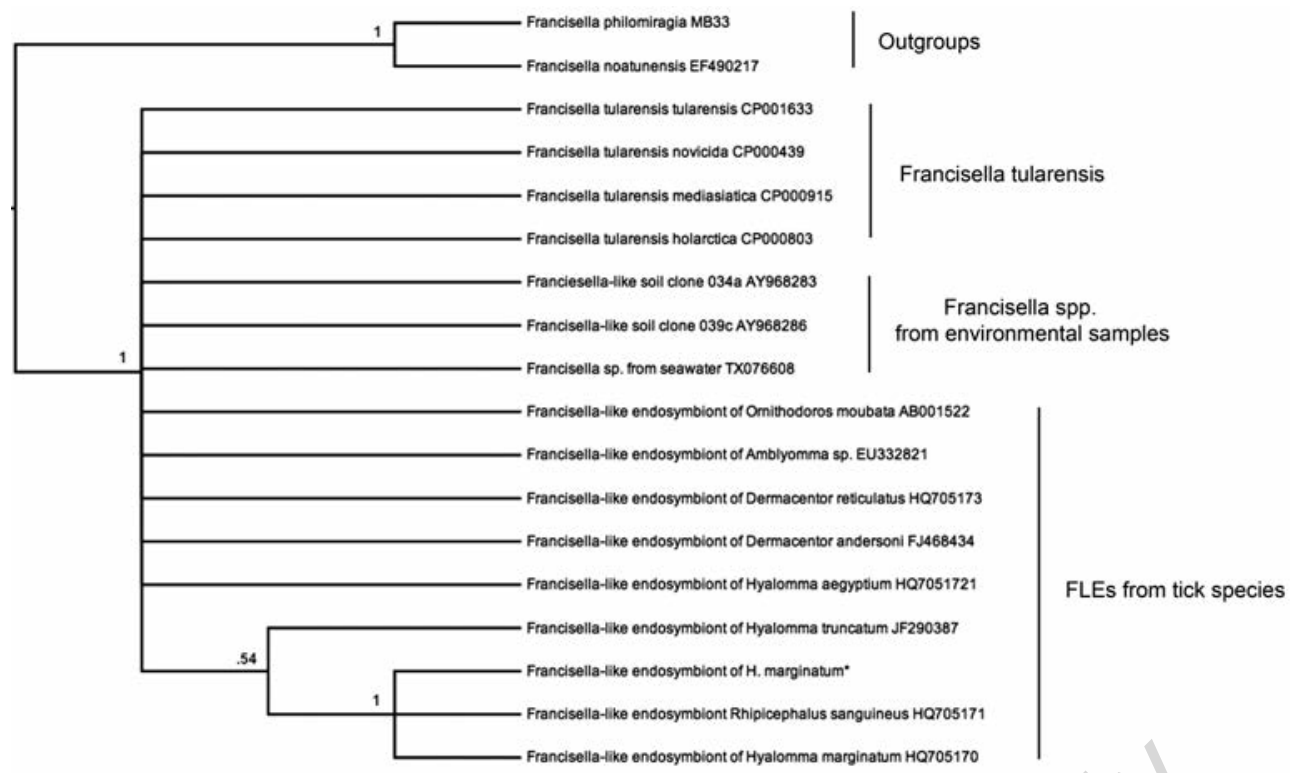

Figure 1. Bayesian consensus cladogram of Francisella spp. 16S rRNA gene, Bayesian posterior probability (BPP) values are reported above each node; branches with BPP values less than 0.5 were collapsed. ${ }^{*}$ The sequence obtained in the present study.

12S rRNA PCR; the PCR products were sequenced and morphological identification was confirmed by BLAST analysis (100\% identity with $H$. marginatum marginatum; Accession number AF150034).

All the specimens tested negative in PCR for the presence of Rickettsia spp., Coxiella burnetii, Borrelia burgdorferi and M. mitochondrii; while 3 specimens collected from 2 different sheep hosts (2 females and one male, $8.8 \%$ of prevalence) were positive for Francisella $16 \mathrm{~S}$ rRNA amplicons. No nucleotide differences were recovered between the three consensus sequences after a pairwise comparison. BLAST analysis performed on the 3 sequences confirms their identity (99\%) with Francisella-like endosymbiont. The best hit of the sequences were the FLEs of Rhipicephalus sanguineus and of $H$. $m$. marginatum, with a difference of one nucleotide (pairwise p-distance $=0.15 \%$ ).

Phylogenetic analyses were performed on a dataset of a $660 \mathrm{bp}$ of the bacterial 16S rRNA composed of eighteen taxa belonging to Francisella spp. from different origin (e.g., pure culture, soil samples, seawater, tick endosymbionts) in order to understand the relationships of the newly sequenced bacterial strains. Bayesian analysis (Figure 1) confirms that Francisella spp. harbored by $H$. marginatum collected from livestock on Socotra Island cluster within the group of tick FLEs. The new sequence clusters with a BPP of 1 within a well-supported group formed by two FLEs previously detected from $H$. marginatum and Rhipicephalus sanguineus collected from Bulgaria.

\section{Discussion}

This is the first study on ticks collected from livestock on Socotra Island and on the harbored bacteria. Gram-negative bacteria belonging to the genus Francisella are known to be distributed mainly in the northern hemisphere (Foley \& Nieto, 2010). Within this group there are bacteria of medical and veterinary importance, such as the etiological agent of Tularemia, F. tularensis and the FLEs of tick. At present, FLEs have been identified in both soft (genus Ornithodoros) and hard
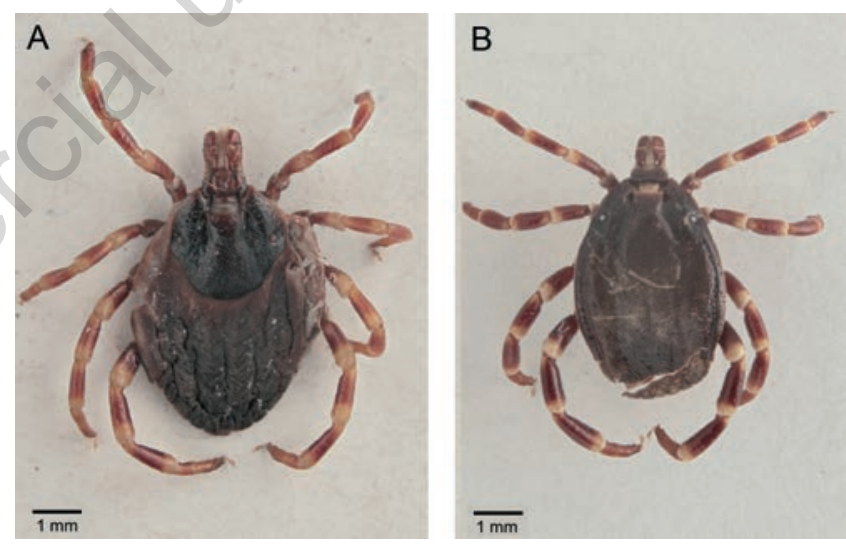

Figure 2. Dorsal view of Hyalomma marginatum: (A) female and (B) male.

(Amblyomma, Dermacentor, Rhipicephalus, Hyalomma) ticks, furthermore their pathogenic role is unknown even if genes implicated in the pathogenicity of $F$. tularensis have been detected (Machado-Ferreira $e t$ al., 2009). The results obtained disagree with the trees obtained in a previous study that have suggested the monophyly of the Francisellalike tick endosymbionts. These discrepancies are due to the fact that we used a fragment of the 16S rRNA that does not provide enough information for these relationships to be clarified.

Considering the importance to human health of bacteria of the genus Francisella, our results could help control new emerging diseases on Socotra Island.

In fact, this study provides the first evidence of Francisella-like endosymbionts harbored by ticks collected from livestock on Socotra Island, and should alert physicians and veterinarians working within the region to the possibility of infection from this organism. 


\section{References}

APANASKEVICH D.A, HORAK I.G., 2008 - The genus Hyalomma Koch, 1844: $\mathrm{V}$ - re-evaluation of the taxonomic rank of taxa comprising the H. (Euhyalomma) marginatum Koch complex of species (Acari: Ixodidae) with redescriptions of all parasitic stages and notes on biology. - Int. J. Acarol. 34: 13-42.

BEATI L., KEIRANS J.E., 2001 - Analysis of the systematic relationships among ticks of the genera Rhipicephalus and Boophilus (Acari: Ixodidae) based on mitochondrial 12S ribosomal DNA gene sequences and morphological characters. - J. Parasitol. 87: 32-48.

BERRI M., LAROUCAU K., RODOLAKIS A., 2000 - The detection of Coxiella burnetii from ovine genital swabs, milk and fecal samples by the use of a single touchdown polymerase chain reaction. - Vet. Microbiol. 72: 285-293.

CASTRESANA J., 2000 - Selection of conserved blocks from multiple alignments for their use in phylogenetic analysis. - Mol. Biol. Evol. 17: $540-552$

EDGAR R.C., 2004 - MUSCLE: a multiple sequence alignment method with reduced time and space complexity. - BMC Bioinformatics. 5:113.

EPIS S., SASSERA D., BENINATI T., LO N., BEATI L., PIESMAN J., et al., 2008 - Midichloria mitochondrii is widespread in hard ticks (Ixodidae) and resides in the mitochondria of phylogenetically diverse species. - Parasitology 135: 485-494.

ESTRADA-PEÑA A., JAMESON L., MEDLOCK J., VATANSEVER Z., TISHKOVA F., 2012 - Unraveling the ecological complexities of tickassociated Crimean-Congo hemorrhagic fever virus transmission: a gap analysis for the Western Palearctic. Vector Borne Zoonotic. Dis. 12: 743-52.

FOLEY J.E., NIETO N.C., 2010 - Tularemia. - Vet. Microbiol. 140: 332 338.

GIRDLER R.W., STYLES P., 1974 - Two stage Red Sea floor spreading. Nature 247: 7-11.

FORSMAN M., SANDSTROM G., SJOSTEDT A., 1994 - Analysis of $16 \mathrm{~s}$ Ribosomal DNA sequences of Francisella strains and utilization for determination of the phylogeny of the genus and for identification of strains by PCR. - Int. J. Syst. Bacteriol. 44: 38-46.

HOOGSTRAAL H., 1956 - African Ixodoidea. I. Ticks of the Sudan (with special reference to Equatoria Province and with preliminary reviews of the genera Boophilus, Margaropus and Hyalomma). U.S. Navy, Washington, DC: 1101.

HOOGSTRAAL H., 1979 - The epidemiology of tick-borne CrimeanCongo hemorragic fever in Asia, Europe and Africa. - J. Med. Entomol. 15: 307-417.

HORAK I.G., CAMICAS J.L., KEIRANS J.E., 2003. The Argasidae, Ixodidae and Nuttalliellidae (Acari: Ixodida): a world list of valid tick names. - Exp. Appl. Acarol. 28: 27-54.

HUELSENBECK J.P., RONQUIST F., 2001 - MRBAYES: Bayesian inference of phylogenetic trees. Bioinformatics. 17: 754-755.
IVANOV I.N., MITKOVA N., REYE A.L., HÜBSCHEN J.M., VATCHEVADOBREVSKA R.S., DOBREVA E.G., et al., 2011 - Detection of new Francisella-like tick endosymbionts in Hyalomma spp. and Rhipicephalus spp. (Acari: Ixodidae) from Bulgaria. - Appl. Environ. Microbiol. 77: 5562-5565.

JONGEJAN F., UILNBERG G., 2004 - The global importance of ticks. Parasitology 129: S3-S14.

LABRUNA M.B., WHITWORTH T., HORTA M.C., BOUYER D.H., MCBRIDE J.W., PINTER A., et al., 2004 - Rickettsia species infecting Amblyomma cooperi ticks from an area in the state of São Paulo, Brazil, where Brazilian spotted fever is endemic. - J. Clin. Microbiol. 42: 90-98.

LANAVE C., PREPARATA G., SACCONE C., SERIO G., 1984 - A new method for calculating evolutionary substitution rates. - J. Mol. Evol. 20: 86-93.

LO N., BENINATI T., SASSERA D., BOUMAN E.A., SANTAGATI S., GERN L., et al., 2006 - Widespread distribution and high prevalence of an alpha-proteobacterial symbiont in the tick Ixodes ricinus. Environ. Microbiol. 8: 1280-1287.

MACHADO-FERREIRA E., PIESMAN J., ZEIDNER N.S., SOARES C.A., 2009 - Francisella-like endosymbiont DNA and Francisella tularensis virulence-related genes in Brazilian ticks (Acari: Ixodidae). - J. Med. Entomol. 46: 369-374.

MANILLA G., 1998 - Fauna d'Italia Ixodoidea. - Calderini, Bologna: 280.

MARCONI R.T., GARON C.F., 1992 - Identification of a third genomic group of Borrelia burgdorferi through signature nucleotide analysis and 16S rRNA sequence determination. - J. Gen. Microbiol. 138: 533-536.

NAVA S., GUGLIELMONE A.A, MANGOLD A.J., 2009 - An overview of systematics and evolution of ticks. - Front. Biosci. 14: 2857-2877.

PAROLA P., RAOULT D., 2001 - Tick-borne bacterial diseases emerging in Europe. - Clin. Microbiol. Infect. 7: 80-83.

POSADA D., 2008 - jModelTest: phylogenetic model averaging. - Mol. Biol. Evol. 25: 1253-1256.

SASSERA D., LO N., EPIS S., D’AURIA G., MONTAGNA M., COMANDATORE F., et al., 2011 - Phylogenomic evidence for the presence of a flagellum and $\mathrm{cbb}(3)$ oxidase in the free-living mitochondrial ancestor. - Mol. Biol. Evol. 28: 3285-3296.

SONENSHINE D.E., 1991 - Biology of ticks, Vol. 1. - Oxford Univ. Press, New York, NY: 447.

SONENSHINE D.E., 1993 - Biology of ticks, Vol. 2. - Oxford Univ. Press, New York, NY: 465.

STARKOFF 0., 1958 - Ixodoidea d'Italia, studio monografico. - Il pensiero scientifico, Roma: 384 .

TAMURA K., PETERSON D., PETERSON N., STECHER G., NEI M., KUMAR S., 2011 - MEGA5: molecular evolutionary genetics analysis using maximum likelihood, evolutionary distance, and maximum parsimony methods. - Mol. Biol. Evol. 28: 2731-2739.

WILLEMS H., THIELE D., FRHLICH-RITTER R., KRAUSS H., 1994 Detection of Coxiella burnetii in cow's milk using the polymerase chain reaction (PCR). - J. Vet. Med. Ser. B 41: 580-587. 